\title{
What make cities sustainable? Barcelona and Istanbul
}

\author{
Ç. C. Türkyılmaz \\ Yildiz Technical University, Istanbul
}

\begin{abstract}
Barcelona has been one of the most active cities of the world over the last 20 years in terms of urban planning. From the first changes in the 1980s to today, it has been seen that Barcelona meets the new economic, social and cultural requirements of a rapidly changing world and proceeds step by step to be one of the world's leading cities.

Istanbul, one of the most dynamic cities of the world, has been rated among Rome, Barcelona, Amsterdam, Paris and London as a leading city of Europe. Today, the city of Istanbul is considered an international brand image, especially after serving as the 2010 European Capital of Culture. While several public space projects have been produced for Istanbul, most of them have important problematic features particularly with regard to applicability.

In this study, some urban public spaces projects from Barcelona and Istanbul are selected as case studies. Selected projects are examined from the standpoint of the essential features of sustainable urban public spaces. These can be explained as follows:

- Identity; all physical, social, cultural aspects of spaces and its relation with the city,

- Accessibility and permeability; physical, visual and symbolic accessibility, the degree of easiness in the circulation of space,

- Multi-functionality; to combine different functions,

- Flexibility; to meet different requirements of users, to facilitate different activities.

The chosen projects are Maremagnum and Diagonal Mar from Barcelona, Meydan and Santralistanbul from Istanbul. The reasons for selection of these projects are to make an important contribution of the sustainable urban development of their areas.
\end{abstract}


The examination has shown that identity and multi-functionality are the most important urban public space features for both cities. With regard to accessibility and permeability, Santralistanbul and Maremagnum are the most successful projects. Santralistanbul is also the most successful one from the standpoint of flexibility.

Keywords: $\quad$ sustainability, Barcelona, Istanbul, Maremagnum, Diagonal Mar, Meydan, Santralistanbul.

\section{Introduction}

Sustainability is a world view aiming to meet economic, environmental and social needs without any harm of the living conditions of future generations [1]. The concept of 'sustainability' in its modern sense emerged in the early 1970s in response to dramatic growth in understanding that modern development practices were leading to worldwide environmental and social crises [2]. Although the sustainability concept developed according the discussions within the frame of the concept of eco-development, the questioning on the human-living environment has been long known. It is defined by ecologists that environmentcentred approaches began with the relationship of human communities between nature [3].

In terms of design, the concept of sustainability is examined, considering architecture and urban scale. Sustainable architecture is all kinds of construction activities taking into account future generations which give priority to the use of renewable sources of energy and use energy, water, materials and space in the most efficient way in any circumstances. In other words, it is the art of fulfilling people's space requirements without jeopardizing the presence and future of natural systems [4]. Sustainable architecture is defined by Kremers (1995) as an architectural design approach aiming to minimize the consumption of resources in order to reduce the usage of natural resources [5].

Sustainable urban design aims to achieve a homogeneous environment compatible with nature and interested in the quality of human life within the ecosystem [6]. Sustainable urban design is a framework that draws attention to the immense opportunity to redesign the built environment in a manner that supports a higher quality of life and human health [7].

\section{The sustainable city}

Sustainable city emerges the union of the concepts of sustainable architecture and sustainable urban design. Bayram [8] defines the sustainable city as a continuous structure which brings social and economic interest together with the environment and energy issues in a compatible format. According to Van Geenhuisan and Nijkamp [9], the sustainable city is an urban area harmonizing the socio-economic interest with energy-related concerns in order to ensure the continuity of change. The sustainable city also prevents irreversible destruction of natural values and adopts the form of compensatory growth fulfilling the needs of the present and the next generations. 
According to Al Hinkawi [10], there are several difficulties in making an overall definition of sustainable city. Among them are different physical and human characteristics, different economic and social wishes; different social and cultural beliefs. It is possible to say that each sustainable city has its unique origin. Therefore, all kinds of efforts regarding sustainability could be with harmony of the unique origin of the city.

There are three main objectives of the concept of sustainable urban development:

- Overcoming the problem of improvement of the quality of life for people living in urban areas.

- Strengthening the city's ability to sustain its existence.

- Questioning the existing production and consumption patterns for the transformation of the city's resources [11].

Sustainable cities have their own participatory city characteristics. These characteristics have been defined by designing important urban projects. Cultural areas, educational areas, transportation areas, financial centres, health centres, tourism centres, retail centres etc., are among important land use which provide new identity and vision for the city. When these areas have been designed regarding sustainability, life quality of the cities can be improved effectively. In this study, the chosen urban projects from Barcelona and Istanbul have combined different functions and make a important contribution of identity and vision of both the local area and the city itself.

\section{Barcelona and Istanbul: a basic/fundamental view on urban development}

Barcelona has been one of the most active cities of the world over the last 20 years in terms of urban planning. From the first changes in the 1980s to today, it has been seen that Barcelona meets the new economic, social and cultural requirements of a rapidly changing world and proceeds step by step to be one of the world's leading cities.

By 1987, when Barcelona began to focus its attention elsewhere, more than 100 urban space projects had been completed, beginning with small-scaled urban plazas and ending with extensive improvements to the Moll de la Fusta along Barcelona's waterfront; the first instalment of the Rondas. Today, the number of completed projects is more than 150, as each of the separate districts undertakes its own projects, following the lead of the earlier works program. Three kinds of urban public space projects, plazas, parks and streets were completed under the initial program. Attention then turned toward other sorts of related public improvements in housing, schools and transportation [12].

The success of Barcelona's urban spaces program has been based on several criteria. These criteria can be summarized as follows:

- A strong emphasis on the continuity of the city's traditional morphology.

- A strong commitment to diversity in the social arrangement and expression of projects.

- Multiple uses of public spaces. 
- Considerable local participation and democratic interaction between elements of the government and civil societies.

Unfortunately, problems have been encountered with such definitive design approaches, even with considerable local district participation. Administrative naivety and oversight for instance, prevented the allocation of adequate resources for project maintenance, leaving a number of the earlier projects in need of considerable refurbishing and some even in sad disrepair [12].

Istanbul, one of the most dynamic cities of the world, has been rated among Rome, Barcelona, Amsterdam, Paris and London as a leading city of Europe. Today, the city of Istanbul has been considered an international brand image especially after serving as the 2010 European Capital of Culture.

Although the effect of globalization began to be felt from the 1980s, the idea that it is necessary to provide a new urban identity for the city of Istanbul, in relation with the new global dynamics, gained importance at the beginning of the 21st century. Urban design projects were an important field of action after the 1980s. A considerable emphasis was given to the implementation of new projects in order to accelerate economic growth in Turkey.

Contemporary urban spaces programs in Istanbul are conducted by various institutions and organizations. Among them, the most important called Istanbul Metropolitan Planning Office (IMP) was established in 2004, under the supervision of local government in order to make the planning and design studies of Istanbul, with the mission of dialogue and negotiation based on participatory platforms. Although IMP has produced several urban design and urban transformation projects, most of them have important problematic features particularly with regard to applicability. For instance, Zeytinburnu District Urban Transformation Project, Ayazma District Urban Transformation Project and Yarımburgaz District Urban Transformation Project were highly criticized by civil societies.

The applicability of urban design and urban transformation projects of Istanbul is relatively low compared to Barcelona. The reasons for this can be summarized as follows:

- Poor attention to the integrity and sustainability of traditional urban morphology of the city.

- Inconsistent policies of local governments.

- Inattention to public participation and uncommunicative attitudes of local governments to civil societies.

- Poor emphasis on multi-functionality, flexibility and applicability of new proposals.

\section{Selected projects}

\subsection{Santralistanbul}

Santralistanbul [14] is one of the important urban transformation and renewal project in Istanbul. The complex contains different functions comprehensively. The Museum of Energy building came about with the conservation of 
Silahtarağa Power Plant, the Ottoman Empire's first urban-scale power plant. As a result of conversion of workshop and storage buildings of the former power plants, Tamirane and Otto Santral, Krek Theatre/performance space (as dining, refreshment and entertainment venues) has emerged. The Main Gallery building is a contemporary art museum of contemporary art exhibitions and cultural activities, received the prize of "International Architecture Awards 2010". Istanbul Bilgi University is also located on the Santralistanbul area [13].

Internal spatial arrangements of old buildings regulated mostly preserving their original conditions. There are existing protected machinery spaces, turbine generating sets, a control room and a new energy playground in the Museum of Energy. The Main Gallery is a new construction; a 5-storey building skeleton composed of reinforced concrete surrounded by a porous metal shell. Educational units of Bilgi University are also new buildings [13].

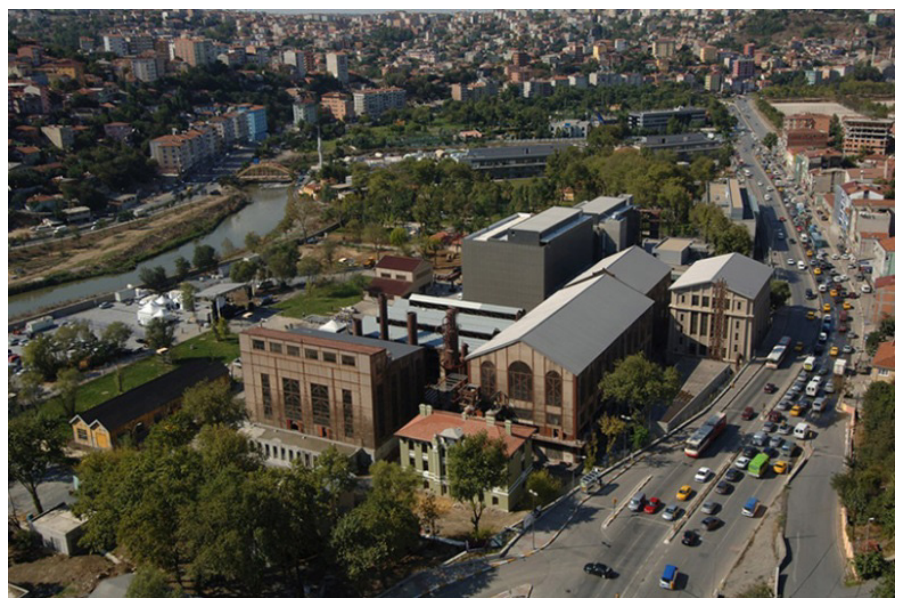

Figure 1: $\quad$ Aerial view of Santralistanbul [14].

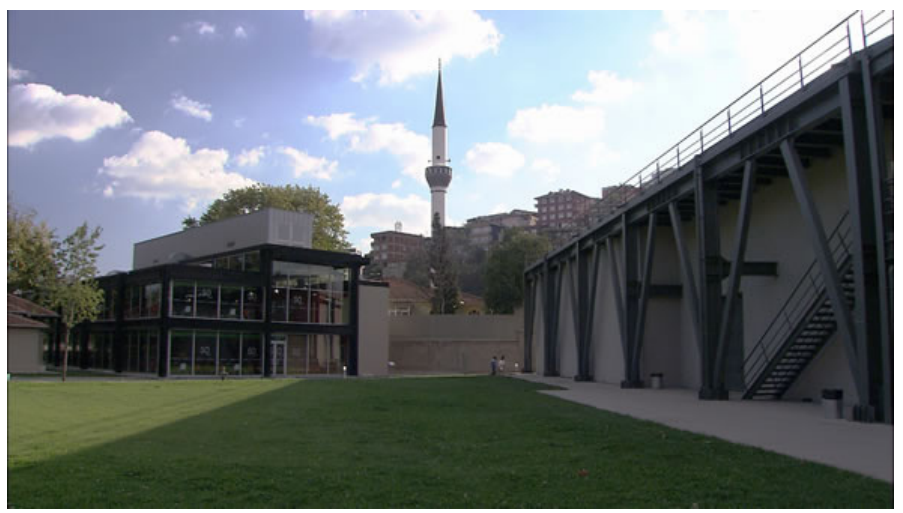

Figure 2: $\quad$ A view from the garden of Santralistanbul [15]. 
Santralistanbul [15] is one of the new urban images of Istanbul. It has several positive impacts on the development of its surroundings. For instance,

- it hosts various cultural activities beside being an training centre;

- it increases social integration as a public platform;

- it provides a stronger transportation network for the public;

- it gives emphasis on the continuity of the city's traditional morphology;

- it encourages local participation, diversity and communication as a cultural platform.

\subsection{Meydan}

Meydan complex [18] is designed by the Spanish architect Alejandro Zaeoro Polo. Nearly all of the shopping mall projects are like closed boxes in Istanbul. In contrast, this building is designed as a shopping square; "Meydan" means a market place or meeting place in Turkish [16]. The idea of a shopping square is established with the integration of green roofs and an open market where people can spend pleasant time by retail activities, place.

The existing differences in elevation are used to make an image of a green hill. That green hill serves as the roof of the complex and the green roof provides a smooth transition to the wide shopping square. Furthermore, by various usages of ramps and stairs, different landscapes are presented to users [17].

The roof of the complex is extensively covered with vegetation - some parts can be walked on - and fitted also with roof lights that provide daylight and air conditioning to the interior, creating a small park with a square in the centre. In the building, 30 thousand square meters of 55 thousand square meters roof space is used as a green space. So grass-covered roofs filter dust and harmful substances in the air and also serve as a green oasis in the midst of Umraniye. In addition, plant soil contributes to heat insulation and provides energy savings [16].

Meydan is also an energy efficient building. A geothermal energy system is used for heating and cooling. 1.3 million kilowatt hours of primary energy have

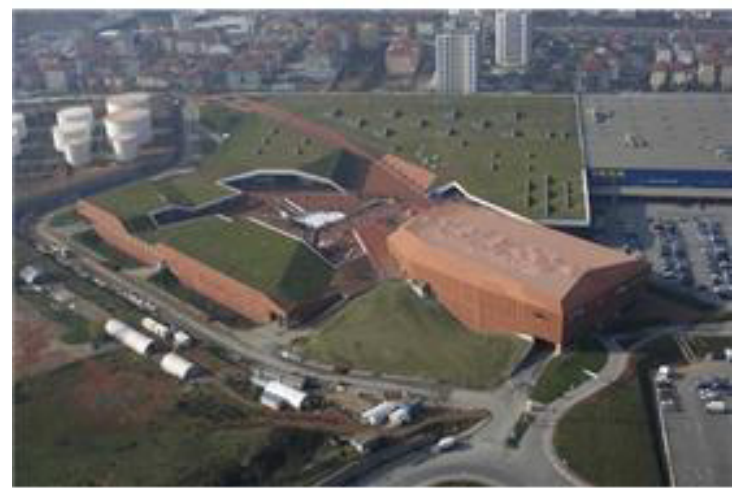

Figure 3: $\quad$ Aerial view of Meydan [18]. 
been saved by this system. This system has also prevented giving approximately 350 tons of carbon dioxide to nature per year [17].

The provision of underground car parking, which is a major part of circulation strategy, liberating a substantial amount of ground floor space to be used for landscaped areas and a new urban square in the centre of the scheme. And as a social role, Meydan aims to perform not just as a proficient retail complex but as a true urban centre for the future development of one of the fastest growing areas in Istanbul [16].

\subsection{Maremagnum}

Before the Barcelona Olympics in 1992, Port Vell, the city's old obsolete harbour, was only a run-down area with empty warehouses, industrial buildings, refuse dumps and railroad yards. With the application of one of the most drastic urban renewal projects, the area was transformed into a yacht basin and entertainment centre, opening the city up to the sea. Today, Port Vell is a very touristic area, with the Barcelona Aquarium, the Catalonia History Museum and the Maremagnum shopping centre as some of its main attractions [19].

Maremagnum [21, designed by Helio Pinon and Alberto Viaplana, was constructed in 1995 and was the first waterfront shopping centre in Spain. During 2005, the building was successfully refurbished and repositioned, transforming into an attractive retail destination with top fashion brands, good

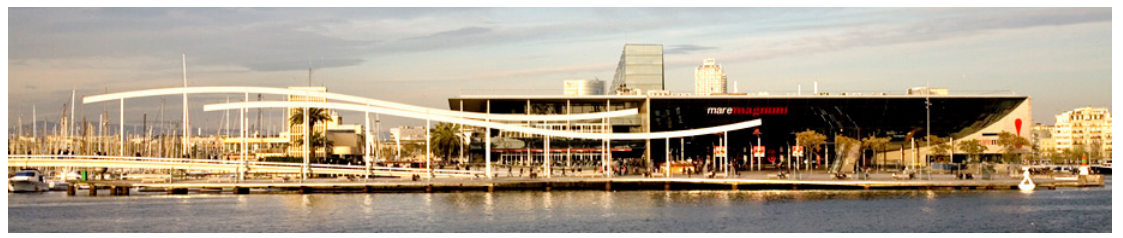

Figure 4: $\quad$ Rambla de Mar and Maremagnum [20].

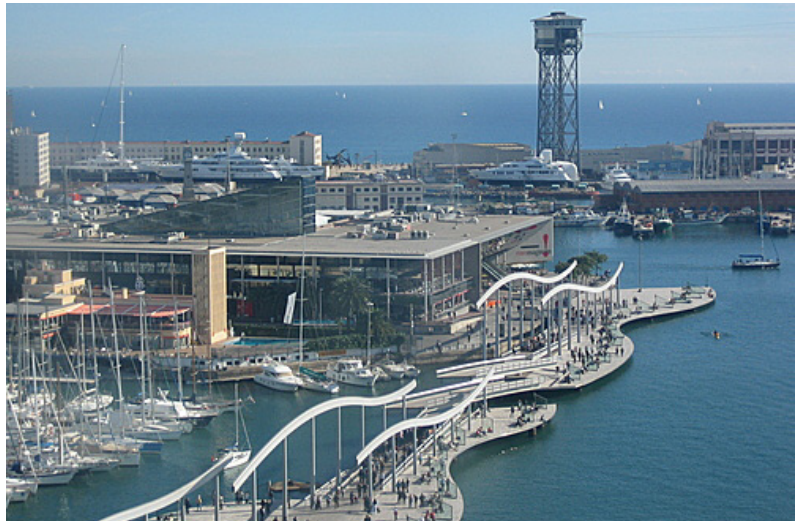

Figure 5: $\quad$ Aerial view of Maremagnum [21]. 
quality restaurants and recreational facilities. The coastal road was moved underground and a wide pedestrian promenade called Rambla de Mar connecting La Rambla to Port Vell was designed [20].

The usage of marine heat exchangers in coastal buildings has been increased recently. The air conditioning and heating of Maremagnum, situated just next to the Mediterranean Sea is also performed by marine heat exchangers. Water from the harbour is used for the pre-conditioning of shops, restaurants, working areas and special rooms as well as contributing to the ventilation of common areas and the car park. The system works by collecting sea water, using 4 extraction pumps, which is delivered to the engine room situated in the basement floor of the building and passed through a heat exchanger. This system will supply or absorb the heat from the condensate seawater circuit depending on the building energy demand. Average operational conditions are 1,728,263 kcal/h and 1.60 litres/second (6 renewals/hour) [22].

\subsection{Diagonal Mar}

The area between the seafront and the Besos River was previously made up of slums and poor areas surrounding the neighbourhoods of La Mina, El Maresme and Poblenau. Under the new name Diagonal Mar [23], in reference to its proximity to the sea and Avinguda Diagonal renovation and urban transformations started in the late 1990s.

The area contains a wide functional variety from residential buildings to a 34acre public park. It also includes Catalunya's largest shopping centre called Centre Comercial Diagonal Mar. Diagonal Mar Shopping Centre was designed by the American architect Robert A. M. Stern. It seeks to adapt the typology of the typical American mall, which is suburban and introspective, to a fringe location that aspires to the urbanity of a city center. Shops open both inward to three-storey-high sky lit galleries and outward to the street. At the top level, restaurants spill out onto an outdoor plaza with views to the adjacent park and the sea beyond [24].

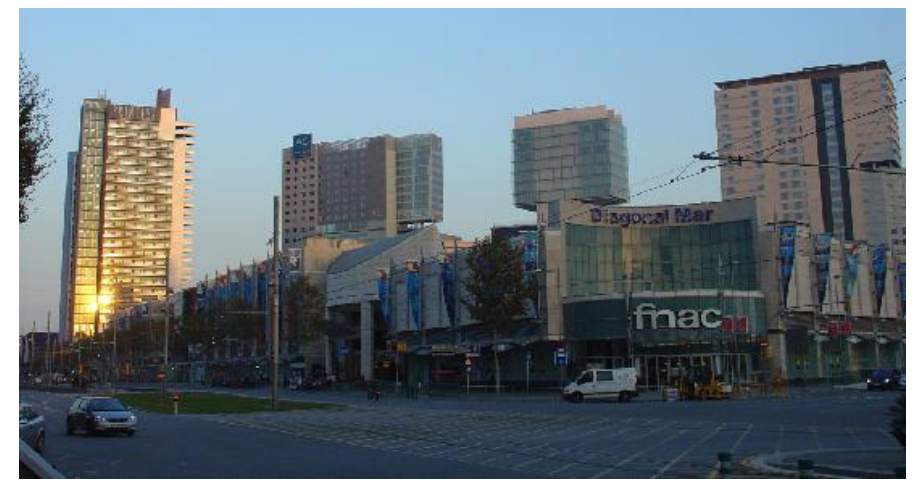

Figure 6: $\quad$ A view from Diagonal Mar [23]. 
Even though Diagonal Mar has the "Urban Land Institute Award for Excellence”, it is highly criticised by local architects such as Oriol Bohigas, Juli Capellas, Josep Maria Montaner. For them, the development of the shopping centre is disappointing and disturbed, and the building itself is just car friendly and an example of a "look but do not touch" attitude [25].

Diagonal Mar is also criticised of creating a gated community with a semiprivate atmosphere. This has generated distrust amongst neighbouring communities. The park and buildings are surrounded by large fences that create a sense of exclusion. At night, when the gates are locked, the district becomes a barrier, effectively sealing off access to the sea for inland communities [25].

\section{The examination of selected projects}

In this study, some urban public space projects from Barcelona and Istanbul are selected as case studies. Selected projects are examined from the standpoint of the essential features of sustainable urban public spaces. These can be explained as follows:

- Identity; all physical, social, cultural aspects of spaces and its relation with the city.

- Accessibility and permeability; physical, visual and symbolic accessibility, the degree of easiness in the circulation of space.

- Multi-functionality; to combine different functions.

- Flexibility; to meet different requirements of users, to facilitate different activities.

The chosen projects from Barcelona and Istanbul were evaluated by a scoring system (Table 1.)

Table 1: $\quad$ The comparison of selected projects.

\begin{tabular}{|l|c|c|c|c|c|}
\hline & Identity & $\begin{array}{c}\text { Accessibility and } \\
\text { permeability }\end{array}$ & $\begin{array}{c}\text { Multi- } \\
\text { functionality }\end{array}$ & Flexibility & TOTAL \\
\hline Santralistanbul & 5 & 5 & 5 & 5 & 20 \\
\hline Meydan & 4 & 3 & 4 & 4 & 15 \\
\hline Maremagnum & 4 & 5 & 4 & 3 & 16 \\
\hline Diagonal Mar & 3 & 2 & 3 & 2 & 10 \\
\hline
\end{tabular}

Examination has shown that identity and multi-functionality are the most important urban public space features for both cities. With regard to accessibility and permeability, Santralistanbul and Maremagnum are the most successful projects. Santralistanbul is also the most successful one from the standpoint of flexibility.

Although Istanbul, with a total score of 35, is higher than Barcelona's total score (26), it does not provide evidence for the comparison of sustainable features. Barcelona has a relatively long and strong history of urban space programs, and the application and results of projects have been mostly positive impacts on the sustainability of the city. It is also possible to study various kinds of buildings and urban projects in Barcelona with regard to sustainability. 
However, the application of sustainable projects is still limited in Istanbul and their contribution of the continuity and the integrity of traditional morphology of Istanbul is open to discussion.

Although there are several discussions on urban space programs of Barcelona, the city itself, with its highly historical awareness and aesthetic perception, can be used as a model for the Istanbul case. Beside Barcelona, some other cities such as Bogota, Santiago, Brasilia, Copenhagen, New York, Phoenix, Detroit, Peking, Brighton, Rio de Janeiro, Cape Town, New Orleans and Stuttgart should be examined in order to achieve a sustainable development model for the Istanbul case.

\section{Conclusion}

Providing the sustainability of cities is not only bringing solutions to environmental problems but is also improving the quality of contemporary life. Once the requirements of present cities are fulfilled, the formation of sustainable spaces where future generations live comfortably can be achieved. It is inevitable to question the existing system and make necessary radical changes in order to create sustainable cities.

Despite the fact that each city has its unique characteristics, sustainable cities can be designed according to some common criteria such as social integrity, environmental respect, cultural diversity, economic conditions, local participation, democratic communication and resource management.

Architects must be aware of the importance of environmental, social and physical sustainability since their design decisions determine the consumption of resources. Architects should reconsider their view of nature for the sustainability of the world and the human being. Sustainability should be the most important issue shaping the design of today and the future.

\section{References}

[1] WCED, (World Commission on Environment and Development, Brundtland Report (Our Common Future), 1987, http://worldinbalance.net /agreements/1987-brundtland.php.

[2] Bostancı, S.H. \& Sancar O., Creating healthy university criteria for environmental sustainability. CAUMME 2012, International Symposium Global Impacts and Local Changes. eds. N. Diker, Istanbul, pp. 417-435, 2012.

[3] Beyhan, G., Sürdürülebilir ve ekolojik yerleşim özelliği taşıyan vernaküler mimari miras; Isparta Dere mahallesi Örneği. International Ecological Architecture and Planning Symposium, Uluslararası Ekolojik Mimarlık ve Planlama Sempozyumu. eds. P. Engincan, H. Yaşar, M. Uçak, Antalya, Turkey, pp. 316-325, 2009.

[4] Sev, A., Sürdürülebilir Mimarlık. YEM Yayınları, 2009, (in Turkish).

[5] Akansel, S., Kaprol, T., Varlı, E., Gencer, İ., Sürdürülebilir kırsal konut planlamasında kamu/üniversite İşbirliği: Edirne örneği. International 
Ecological Architecture and Planning Symposium, Uluslararası Ekolojik Mimarlık ve Planlama Sempozyumu. eds. P. Engincan, H. Yaşar, M. Uçak, Antalya, Turkey, pp. 227-231, 2009.

[6] Moughtin, C., Urban Design: Green Dimensions. The Architectural press, 2006.

[7] Oktay, D., Sustainable urbanism revisited: A holistic framework based on traditions and contemporary orientations. Green and ecological technologies for urban planning: Creating smart cities, eds. O., YalçınerErcoşkun, USA, pp. 17-37, 2012.

[8] Bayram, F., Sürdürülebilir Kentsel Gelişme: Araçlar, Yaklaşımlar ve Türkiye. Mülkiyeliler Birliği Yayınları, Ankara, 2001 (in Turkish).

[9] Van Geenhuisan, M., Nijkamp, P., Sürdürürülebilir kent nasıl planlanmalı? Toplum ve Bilim Dergisi, s.131, 1994 (in Turkish).

[10] Al-Hinkawi, W.S., Sustainable urban shape (Compact City), Sustainable urban projects in UAE, Bahrain and Kuwait. CAUMME 2012, International Symposium Global Impacts and Local Changes. eds. N. Diker, Istanbul, pp. 270-293, 2012.

[11] Seçer Kariptaş, F., Sürdürülebilirlik kavramının kentler üzerindeki etkisi: sürdürülebilir kentleşme. International Ecological Architecture and Planning Symposium, Uluslararası Ekolojik Mimarlık ve Planlama Sempozyumu. eds. P. Engincan, H. Yaşar, M. Uçak, Antalya, Turkey, pp. 435-438, 2009.

[12] Rowe, P.G., Building Barcelona. A second Renaixença. Barcelona Regional and ACTAR, 2006.

[13] Düzgün, H., Aladağ, H., How sustainable are industrial buildings? A study in Golden Horn district. CAUMME 2012, International Symposium Global Impacts and Local Changes. eds. N. Diker, pp. 402-417, 2012.

[14] www.okyanuskoleji.k12.tr (Accessed June 2013).

[15] www.esiweb.org (Accessed June 2013).

[16] Aladağ, H., Düzgün, H., A bird-eye view to sustainable designs in changing cities: Green roofs. Proceedings of the International Conference on "Changing Cities": Spatial, morphological, formal \& socio-economic dimensions. Skiathos island, Greece, pp. 1113-1123, 2013.

[17] Şahin, F., Yılmaz, D., Kavrazi M. Türkiye”nin ilk ekolojik alışveriş merkezi: Meydan. International Ecological Architecture and Planning Symposium, Uluslararası Ekolojik Mimarlık ve Planlama Sempozyumu. eds. P. Engincan, H. Yaşar, M. Uçak, Antalya, Turkey, pp. 252-258, 2009.

[18] http://www.yesilbina.com/Metro-AVM-Umraniye_p12.html (Accessed June 2013).

[19] http://www.barcelonaturisme.com/Port-Vell/_dHcEaVlbphwEUMd45leERsgzSgXfOP5OyepiGDMcsM (Accessed June 2013).

[20] www.maremagnum.es (Accessed June 2013).

[21] www.panoramia.com (Accessed June 2013).

[22] http://en.wikipedia.org/wiki/Marine_heat_exchangers (Accessed June 2013).

[23] www.travel.pod.com (Accessed June 2013). 
120 The Sustainable City VIII, Vol. 1

[24] http://www.ramsa.com/en/projects-search/retail/entertainment.html (Accessed June 2013).

[25] http://www.pps.org/great_public_spaces/one?public_place_id=623 (Accessed June 2013). 